\title{
Overview of Mechanisms and Uses of Trichoderma spp.
}

\author{
Gary E. Harman
}

Cornell University, Geneva, NY 14456.

Accepted for publication 2 September 2005.

\begin{abstract}
Harman, G. E. 2006. Overview of mechanisms and uses of Trichoderma spp. Phytopathology 96:190-194.

Fungi in the genus Trichoderma have been known since at least the 1920 s for their ability to act as biocontrol agents against plant pathogens. Until recently, the principal mechanisms for control have been assumed to be those primarily acting upon the pathogens and included mycoparasitism, antibiosis, and competition for resources and space. Recent advances demonstrate that the effects of Trichoderma on plants, including induced systemic or localized resistance, are also very important. These fungi colonize the root epidermis and outer cortical layers and release bioactive molecules that cause walling off of the Trichoderma thallus. At the same time, the transcriptome and the proteome of plants are sub-

stantially altered. As a consequence, in addition to induction of pathways for resistance in plants, increased plant growth and nutrient uptake occur. However, at least in maize, the increased growth response is genotype specific, and some maize inbreds respond negatively to some strains. Trichoderma spp. are beginning to be used in reasonably large quantities in plant agriculture, both for disease control and yield increases. The studies of mycoparasitism also have demonstrated that these fungi produce a rich mixture of antifungal enzymes, including chitinases and $\beta-1,3$ glucanases. These enzymes are synergistic with each other, with other antifungal enzymes, and with other materials. The genes encoding the enzymes appear useful for producing transgenic plants resistant to diseases and the enzymes themselves are beneficial for biological control and other processes.
\end{abstract}

For about 70 years, Trichoderma spp. have been known to be able to attack other fungi, to produce antibiotics that affect other microbes, and to act as biocontrol microbes $(44,45)$. During this time, we have learned much about their mechanisms of action and how they might be used commercially for various purposes.

Some landmarks along the way include the discoveries that these fungi frequently increase plant growth and productivity (30) either in the presence (9) or absence (30) of other microorganisms and that they can induce disease suppression in soils (11). Composted materials may be suppressive and that suppression may occur in part as a consequence of activities of Trichoderma spp. by several different mechanisms (25), as will be discussed in this session (Hoitink). Further, strains differ remarkably in their abilities to colonize roots (i.e., to be rhizosphere competent) (1) and the most effective strains will colonize roots and provide benefits for at least the life of annual crops (20). In addition, the complex mechanisms of mycoparasitism, which include directed growth of Trichoderma toward target fungi, attachment and coiling of Trichoderma on target fungi, and the production of a range of antifungal extracellular enzymes, were elucidated, initially in large part by I. Chet and his students and colleagues (summarized in Chet [10] and Chet et al. [12]).

Indeed, Trichoderma spp. were demonstrated to be very efficient producers of extracellular enzymes, with cellulases as the first example $(36,37)$. Later, these fungi were found to produce a wide range of other extracellular enzymes and some of these were implicated in the biological control of plant diseases (17). In the early 1990s, a series of papers by a range of labs demonstrated that the mixtures of biocontrol enzymes were very complex, and the genes encoding many of these were isolated and sequenced

Corresponding author: G. E. Harman; E-mail address: geh3@ cornell.edu

DOI: 10.1094/PHYTO-96-0190

() 2006 The American Phytopathological Society (summarized in Benitez et al. [4] and Lorito [31]). The enzymes themselves were found to be fungitoxic and mixtures of enzymes were synergistic in their antifungal properties (34). Different classes of chitinolytic or glucanolytic enzymes from Trichoderma are synergistic as are enzymes from different organisms (34). Genes encoding these proteins have been inserted into plants, where they have been shown to induce resistance to a range of plant-pathogenic fungi $(6,7,35)$. The remainder of this paper will summarize some recent advances.

Trichoderma spp. as opportunistic plant symbionts. A number of plant-associated microbes are free-living and strongly beneficial to plants. Fungi in the genus Trichoderma (21) and rhizobacteria in the genera Pseudomonas, Bacillus, Streptomyces, Enterobacter, and others $(2,38,39,43)$ have evolved multiple mechanisms that result in improvements in plant resistance to disease and plant growth and productivity.

A new set of models of the mechanisms of action of Trichoderma spp. has recently been proposed (21). These new models do not replace others, which may include inhibition of enzymes necessary for pathogens to penetrate plant surfaces (49) and competition for nutrients (16) including those necessary for pathogen propagules to germinate near planted seeds $(26,27)$. There are a number of mechanisms whereby these fungi act as biocontrol agents.

Our understanding of the genetic control of mycoparasitism has changed significantly. It has been known for many years that Trichoderma can sense the presence of target fungi and appeared to grow tropically toward them (13). More recently, the gene encoding green fluorescent protein was inserted downstream of the regulatory regions of genes encoding an endo- and an exochitinase that have biocontrol abilities. When paired with a target fungus, the endochitinase gene is activated before the fungi come into contact, while the activation of the exochitinase occurs only after contact is made (48). Different strains may follow different patterns of induction but the fungi apparently always produce low 
levels of an extracellular exochitinase. Diffusion of this enzyme catalyzes release of cell wall fragments from target fungi and this, in turn, induces expression of fungitoxic cell wall degrading enzymes (8) that also diffuse and begin the attack on the target fungi before contact is actually made $(42,48)$. These cell wall fragments are highly potent inducers of enzymes and induce a cascade of physiological changes within the fungus, including an enhancement in Trichoderma growth. This system will be described more fully in this session by Lorito. Thus, there are numerous ways by which Trichoderma spp. attack or otherwise directly inhibit other fungi.

However, the direct effects of Trichoderma spp. on plants are remarkable and at least as significant as their direct effects on other fungi and have only recently been described. First, the fungi are highly efficient inducers of systemic and localized resistance in plants, a fact perhaps first conclusively demonstrated by Bigirimana et al. (5) although it was suggested by numerous other workers earlier. A recent review lists 11 separate reports demonstrating control by Trichoderma spp. of a wide range of plant pathogens, including fungi, oomycetes, bacteria, and one virus, by elicitation of induced systemic or localized resistance (21). The fungi, especially rhizosphere competent ones, colonize root surfaces and penetrate the epidermis and into the cortex (46). Along the way, the fungi may coil about root hairs in a manner reminiscent of mycoparasitism (46). Once Trichoderma hyphae penetrate the roots, a series of bioactive metabolites from the fungus is produced that induces walling off and biochemical mechanisms that limit growth of the Trichoderma to a small area. This reaction may not always occur; for example, there now are known endophytic Trichoderma strains that colonize vascular systems of certain plants, as will be discussed elsewhere in this session (Samuels). This may be similar to responses of other root colonizing biocontrol fungi including binucleate Rhizoctonia species (29) and nonpathogenic Fusaria (3). The bioactive molecules may include several different proteins (19), avr-like proteins and cell wall fragments released by action of extracellular enzymes, as has been demonstrated in the mycoparasitic reaction (21).

This interaction results in both localized and systemic resistance (21). Among other surprising findings are the demonstration that, contrary to long-held opinion, the ability of $T$. virens to control seedling disease in cotton caused by Rhizoctonia solani is not due to antibiotics or mycoparasitism but is mediated by the abilities of the biocontrol strains to induce terpenoid phytoalexins (28), as will be discussed in this session. T. virens on cotton results in localized resistance, but with most other plant-Trichoderma systems, the resistance induced is systemic (21).

The systems for induced resistance appear to be in at least some ways similar to those induced by rhizobacteria. Yedidia et al. (47) demonstrated that mRNA for pathogenesis-related (PR) proteins was only expressed transitorily in the absence of pathogens. However, if leaves of beans whose roots were colonized by Trichoderma were inoculated with the bacterial pathogen Pseudomonas syringae pv. lachrymans, there was strong expression of mRNA for several different PR proteins. If either the pathogen alone was inoculated onto foliage or T. asperellum was not present on roots, then the induction of the PR transcriptomes did not occur, or occurred at a lower rate $(21,47)$. Thus, in common with the effects of plant growth promoting rhizobacteria, there appears to be a priming effect of the root symbiont that is expressed when the plant is challenged by a pathogen.

The resistance induced may be temporally and spatially distant from the site of application or existence of the Trichoderma. For example, T. harzianum strain T22 (41) was added at transplanting to tomato roots. After 90 to 120 days, symptoms of late blight appeared on the leaves, but in trials over 2 years, there was up to $80 \%$ reduction in disease in the presence compared with the absence of T22 even though T22 was present only on roots (21).
Mention has already been made of the ability of root symbiotic Trichoderma strains to increase plant growth. This effect has been studied for some time in this lab with maize as the system. The general concepts have been published several times and are summarized below. Among the positive effects on maize that have been noted over the past 5 to 10 years in work conducted by Advanced Biological Marketing, Cornell University and others include the following (documented in Harman [20] and Harman et al. [23]):

- Control of root and foliar pathogens

$>$ Induced resistance

> Biological control of diseases by direct attack of plantpathogenic fungi

- Changes in the microfloral composition on roots

- Enhanced nutrient uptake, including but not limited to nitrogen

- Enhanced solubilization of soil nutrients

- Enhanced root development

- Increased root hair formation

- Deeper rooting

For some time, the possibility that different plants respond differently to biocontrol agents or plant symbiotic fungi has been discussed. However, since Trichoderma spp. are broadly effective across a range of plant species, we did not view strong genetic interactions with plants as a major factor. However, in maize this is not true, at least for the enhanced growth response.

There have been more than 500 documented field trials that compared field corn grown from seed, treated or not treated with T. harzianum strain T22, and the average yield increase is about $5 \mathrm{bu} / \mathrm{acre}$. However, trial results have shown tremendous variability, with ranges between $+50 \%$ to actual yield decreases. This clearly indicates that there are uncontrolled or poorly understood variables that affect results. The greatest yield increases appeared when the variety tested had some genetic weaknesses (e.g., Nutridense varieties) or where there were biotic (e.g., anthracnose or rust) or abiotic (e.g., soil compaction, drought, or nutrient insufficiency) stresses present.

The reasons for the occasionally observed yield decreases were at first attributed to unusual field variations, but a large trial (160 hybrids +/- T22 in three different sites in the U.S. corn belt) conducted by a commercial company, Advanced Biological Marketing, suggested that there was a maize genetic component to the interaction of $\mathrm{T} 22$ as well.

A first priority for research at Cornell University was to identify a genetically homozygous inbred that responded strongly to T22. An initial screen resulted in the discovery that seedling growth (measured 2 weeks after planting) of maize inbred Mo17 is strongly enhanced by T22 and that this increased growth response continues for the life of the plant (23). The same treatment also induces systemic resistance. Further, T22 on roots increased levels of total proteins and activity of the putative PR proteins chitinase and $\beta-1,3$ glucanase in both shoots and roots (23).

Field trials and lab experiments have confirmed the observation that there is a maize genetic component to the T22 response. In field trials in 2002, a hybrid, Sgi860 $\times$ Sgi861, was used that had not been evaluated before. The experiment was a replicated block design that compared +/- T22 over a range of organic (composted chicken manure) or inorganic (ammonium nitrate) fertilizer concentrations to give different levels of added nitrogen ranging from 0 to $100 \mathrm{~kg} / \mathrm{ha}$. From the earliest growth of the maize, reduced growth in the presence of T22 was observed regardless of treatment, and the end of the season yields in the presence of T22 were reduced about $7 \%$ over a total of 14 fertilizer treatments.

This hybrid was tested in the 2-week seedling assay developed previously for Mo17. There was a statistically significant reduction in growth in this assay as well. This finding was significant for two reasons, as follows:

- T22 reduced growth of Sgi860 $\times$ Sgi861 both in the field across a range of fertilizer levels and in our lab assay with 2-week-old seedlings. 
- The 2-week seedling assay retrospectively appeared to have predictive ability for the yield performance of maize in the field. This result is consistent with repeated observations that changes in growth of maize by T22 can be observed within a short time of plant emergence from soil and can be tracked throughout the growing season.

The two parental inbreds were evaluated in the 2-week lab growth test and only Sgi861 exhibited growth reduction, while growth of the other parent was only slightly affected by seed treatment with T22. We also made an $F_{1}$ hybrid between Mo17 and Sgi861. The hybrid gave increased growth responses similar to the responses of Mo17.

Thus, a hybrid between a line with little growth response to T22 and a negative responding line gave an $\mathrm{F}_{1}$ hybrid $($ Sgi860 $\times$ Sgi861) that also gave a negative growth response. Another cross between a negative responding line and a strongly positive responding line gave a hybrid $($ Mo17 $\times$ Sgi861) with a strong positive response. These data may suggest that the T22 responses in maize are largely conditioned by dominant genes. Sgi lines are proprietary and we could not proceed further with them, so we examined a series of publicly available lines using the 2-week assay. The responses of various inbred lines are as follows:

- T22 induces strong positive growth responses $>$ Mo17, Mo46, Va26, C103, C123, NYD410, WF9, B14

- T22 has little effect upon plant growth $>$ RD402, RD 6503, Oh43, Pa875, Va17, Va35, RD3013, B73

- T22 negatively affects plant growth $>$ A661 and Pa33

Thus, there clearly are strong genetic components to the response of at least maize to T22.

Strain T22 of $T$. harzianum generally increases plant growth and development and controls diseases in both commercial use and controlled experimental settings (20). However, because of variations in results, it is currently used on only a small percentage of the total maize acreage in the United States. The understanding of its genetic interactions with maize is expected to substantially reduce the variability that has limited its use thus far. Clearly, if T22 was only applied to seeds of varieties that respond positively, then the overall yield benefit should increase and the variability should decrease. Maize also is an ideal crop for application of an inexpensive, long-term method for reducing disease via systemic resistance. Since T22 is a root colonist, only small amounts need to be applied to the seeds for long-term effects. Further, total control is not necessary; even a relatively modest decrease in disease would be a valuable addition to maize culture since foliar fungicides are generally too expensive for field maize.

For nearly all commercial uses of Trichoderma for biological control and for enhancement of plant growth and yield, an understanding of the mechanisms and Trichoderma-pathogen, Trichoderma-plant, and Trichoderma-plant-pathogen interactions is essential. For example, if the maize-Trichoderma interactions are fully understood, and the promise of substantially increased yields are realized, then Trichoderma will be used on a sizable percentage of the total 36 million acres of the crop in the United States. Further, with a clear understanding of mechanisms we can develop strategies to produce improved strains. For example, there was great concern regarding screening techniques for biocontrol strains of Trichoderma; the first and quickest ones were screens for antibiotic production and/or mycoparasitism in petri dish assays. Unfortunately, although the results were frequently clear-cut, they had almost no predictive value for biocontrol efficacy. Therefore, we, and most other labs, used plant-pathogen interaction assays for testing, and this was effective and predictive (24). Petri dish assays as systems for good biocontrol strains had several fundamental drawbacks, based on our current knowledge. One was that delivery and production systems were rudimentary, but the other was the fact that the plant and soil were left out of the assay. If induced resistance is the mechanism by which biological control was achieved, then clearly assays containing only Trichoderma and the pathogen were doomed to fail. Modern screening will assess effects of the candidate strain on the plant, both on roots and on foliage even if the biocontrol agent is present only on roots. Understanding mechanisms and development of rapid screening protocols will involve modern molecular tools such as measuring specific gene expression. This advance alone is expected to pay dividends in practical biological control.

Uses of biological control and related enzymes and the genes that encode them. We know that there is a wide range of chitinolytic and glucanolytic enzymes with possible roles in biological control and no doubt many more will be discovered as the Trichoderma genome and proteome are analyzed. There probably are at least 30 chitinases alone, each with a different gene structure and protein composition. Some have exo-enzyme activity and others act as endochitinases; no doubt there are also chitin deacetylases and chitosanases. There also is a rich mixture of glucanases. Thus, the number of genes and proteins just in these two groups of biocontrol genes is very diverse. Most of the gene products are antifungal.

These enzymes, if they act differently (for example, exo- and endochitinases), are synergistic in their activity. Thus, an effective dose at fifty percent $\left(\mathrm{ED}_{50}\right)$ for a typical chitinase may be around $40 \mu \mathrm{g} / \mathrm{ml}$, but the $\mathrm{ED}_{50}$ for a mixture of an exo and an endo would be about $10 \mu \mathrm{g} / \mathrm{ml}$ of total protein. For a mixture of two chitinases plus a glucanase, the comparable value would be 1 to $3 \mu \mathrm{g} / \mathrm{ml}$ of total protein (32). Furthermore, they are strongly synergistic in their antifungal activities when combined with essentially any chemical fungicide that directly or indirectly has an effect upon the cell membranes of target fungi (33). Thus, it is surprising that these enzymes are not already used in the control of unwanted fungi; however, a major limiting factor has been the lack of availability of large-scale quantities of enzymes for product development.

Other uses for these versatile and stable enzymes exist. For example, very large quantities of crustacean chitin are discarded each year. There is a large market for glucosamine, which is a chemically degraded form of the monomer of chitin, $\mathrm{N}$-acetyl glucosamine (NAG). However, NAG has the potential to be more valuable than glucosamine; for example, it has proven useful in the treatment of inflammatory bowel disease and related bowel disorders (40) while glucosamine lacks this ability. Crustacean chitin is difficult to process chemically to NAG and the material is highly resistant to most chitinolytic enzymes due to its crystalline structure, the presence of calcium and other factors. However, a synergistic mixture of bacterial chitinases and Trichoderma chitinases has proven to give essentially complete release of NAG (14).

In addition, the genes encoding these antifungal proteins have been transferred to plants where they confer resistance to fungal plant pathogens $(6,7)$. Recently, highly resistant rice plants expressing Trichoderma genes have been produced by T. Xu, PRC. The primary impediment to commercial use of Trichoderma genes has been the public resistance to transgenic plants. Because of this, the first commercial use of transgenic plants that contain Trichoderma biocontrol genes may be in China.

Uses of Trichoderma in pollution remediation. Trichoderma spp. probably have significant wide-scale uses in the remediation of pollutants in soils and waters (22). First, as has been noted earlier, highly rhizosphere competent strains of Trichoderma, such as T. harzianum strain T22, enhance root growth of a range of plants. This enhanced root growth, when combined with a plant that hyper-accumulates toxicants, will increase the volume of soil colonized by roots, including enhancement of deep root penetration (20). Further, Trichoderma spp. on roots increase uptake of nitrates and other ions (20) and may also increase uptake of various toxic metals and metalloids. Thus, it should assist in phytoextractive activities. 
Further, Trichoderma spp. are highly resistant to a range of toxicants, perhaps at least in part because of highly active ABC transport systems (21). Included on the list of toxic materials they resist is cyanide. Recently, fungi in the genus Trichoderma were shown to be capable of catabolizing cyanide (18). These fungi constitutively produce cyanide hydratase (EC 4.2.1.66) and rhodanese (thiosulfate sulfurtransferase, EC 2.8.1.1). Experiments were performed in which the fungi were added to soils spiked with cyanide solutions, and then wheat or pea seeds were sowed on this soil mix. In the absence of cyanide, the seedlings grew normally from seed, but the addition of $10 \mathrm{mM}$ cyanide severely limited seedling growth. However, in the presence of any of several different Trichoderma strains, the germinating seeds provided a nutrient source for the fungus, permitting its growth. The fungi produced enzymes that degraded the cyanide and permitted normal growth of seedlings even at 50 or $100 \mathrm{ppm}$.

Recently published research from Cornell University and the University of Southern Illinois, Carbondale, suggests that the shrub willow, Salix eriocephala, is an excellent candidate plant species for phytoremediation of cyanide- and ferrocyanide-contaminated soils and groundwater (15). S. eriocephala plants demonstrated the ability to take up and degrade ferrocyanide in hydroponic cultures with ${ }^{15} \mathrm{~N}$-labeled cyanide or ferrocyanide, yet no cyanide remained in the aerial plant tissues. The combination of Trichoderma with shrub willows is expected to provide an effective method to degrade and remove cyanide and metallocyanides from a variety of polluted sites. These examples are a portion of the potential for use of Trichoderma spp. in remediation of polluted sites.

\section{LITERATURE CITED}

1. Ahmad, J. S., and Baker, R. 1987. Rhizosphere competence of Trichoderma harzianum. Phytopathology 77:182-189.

2. Belimov, A. A., Safronova, V. I., Sergeyeva, T. A., Egorova, T. N., Matveyeva, V. A., Tsyganov, V. E., Borisov, A. Y., Tikhonovich, I. A., Kluge, C., Preisfeld, A., Dietz, K. J., and Stepanok, V. V. 2001. Characterization of plant growth promoting rhizobacteria isolated from polluted soils and containing 1-aminocyclopropane-1-carboxylate deaminase. Can. J. Microbiol. 47:642-652.

3. Benhamou, N., Garand, C., and Goulet, A. 2002. Ability of nonpathogenic Fusarium oxysporum strain $\mathrm{Fo} 47$ to induce resistance against Pythium ultimum infection in cucumber. Appl. Environ. Microbiol. 68:4044-4060.

4. Benitez, T., Limon, C., Delgado-Jarana, J., and Rey, M. 1998. Glucanolytic and other enzymes and their control. Pages 101-127 in: Trichoderma and Gliocladium. Vol. 2. G. E. Harman and C. P. Kubicek, eds. Taylor \& Francis, London.

5. Bigirimana, J., De Meyer, G., Poppe, J., Elad, Y., and Hofte, M. 1997. Induction of systemic resistance on bean (Phaseolus vulgaris) by Trichoderma harzianum. Med. Fac. Landbouww. Univ. Gent 62:1001-1007.

6. Bolar, J. P., Norelli, J. L., Harman, G. E., Brown, S. K., and Aldwinckle, H. S. 2001. Synergistic activity of endochitinase and exochitinase from Trichoderma atroviride (T. harzianum) against the pathogenic fungus (Venturia inaequalis) in transgenic apple plants. Transgenic Res. 10:533543.

7. Bolar, J. P., Norelli, J. L., Wong, K.-W., Hayes, C. K., Harman, G. E., and Aldwinckle, H. S. 2000. Expression of endochitinase from Trichoderma harzianum in transgenic apple increases resistance to apple scab and reduces vigor. Phytopathology 90:72-77.

8. Brunner, K., Peterbauer, C. K., Mach, R. L., Lorito, M., Zeilinger, S., and Kubicek, C. P. 2003. The Nag1 $N$-acetylglucosaminidase of Trichoderma atroviride is essential for chitinase induction by chitin and of major relevance to biocontrol. Curr. Genet. 43:289-295.

9. Chang, Y.-C., Chang, Y.-C., Baker, R., Kleifeld, O., and Chet, I. 1986. Increased growth of plants in the presence of the biological control agent Trichoderma harzianum. Plant Dis. 70:145-148.

10. Chet, I. 1987. Trichoderma-application, mode of action, and potential as a biocontrol agent of soilborne plant pathogenic fungi. Pages 137-160 in: Innovative Approaches to Plant Disease Control. I. Chet, ed. John Wiley \& Sons, New York.

11. Chet, I., and Baker, R. 1981. Isolation and biocontrol potential of Trichoderma harzianum from soil naturally suppressive of Rhizoctonia solani. Phytopathology 71:286-290.
12. Chet, I., Benhamou, N., and Haran, S. 1998. Mycoparasitism and lytic enzymes. Pages 153-172 in: Trichoderma and Gliocladium. Vol. 2. G. E. Harman and C. P. Kubicek, eds. Taylor \& Francis, London.

13. Chet, I., Harman, G. E., and Baker, R. 1981. Trichoderma hamatum: Its hyphal interactions with Rhizoctonia solani and Pythium spp. Microbiol. Ecol. 7:29-38.

14. Donzelli, B. G. G., Ostroff, G., and Harman, G. E. 2003. Enhanced enzymatic hydrolysis of langostino shell chitin with mixtures of enzymes from bacterial and fungal sources. Carbohyd. Res. 338:1823-1833.

15. Ebbs, S., Bushey, J., Poston, S., Kosma, D., Samiotakis, M., and Dzombak, D. 2003. Transport and metabolism of free cyanide and iron cyanide complexes by willow. Plant Cell Environ. 269:1467-1478.

16. Elad, Y. 1996. Mechanisms involved in the biological control of Botrytis cinerea incited diseases. Eur. J. Plant Pathol. 10:2719-732.

17. Elad, Y., Chet, I., and Henis, Y. 1982. Degradation of plant pathogenic fungi by Trichoderma harzianum. Can. J. Microbiol. 28:719-725.

18. Ezzi, M. I., and Lynch, J. M. 2002. Cyanide catabolizing enzymes in Trichoderma spp. Enzyme Microbiol. Technol. 31:1042-1047.

19. Hanson, L. E., and Howell, C. R. 2004. Elicitors of plant defense responses from biological control strains of Trichoderma virens. Phytopathology 94:171-176.

20. Harman, G. E. 2000. Myths and dogmas of biocontrol. Changes in perceptions derived from research on Trichoderma harzianum T-22. Plant Dis. 84:377-393.

21. Harman, G. E., Howell, C. R., Viterbo, A., Chet, I., and Lorito, M. 2004. Trichoderma species-Opportunistic, avirulent plant symbionts. Nat. Rev. Microbiol. 2:43-56.

22. Harman, G. E., Lorito, M., and Lynch, J. M. 2004. Uses of Trichoderma spp. to remediate soil and water pollution. Adv. Appl. Microbiol. 56:313330 .

23. Harman, G. E., Petzoldt, R., Comis, A., and Chen, J. 2004. Interactions between Trichoderma harzianum strain T22 and maize inbred line Mo17 and effects of this interaction on diseases caused by Pythium ultimum and Colletotrichum graminicola. Phytopathology 94:147-153.

24. Harman, G. E., Taylor, A. G., and Stasz, T. E. 1989. Combining effective strains of Trichoderma harzianum and solid matrix priming to improve biological seed treatments. Plant Dis. 73:631-637.

25. Hoitink, H. A. J., Stone, A. G., and Han, D. Y. 1997. Suppression of plant diseases by composts. HortScience 32:184-187.

26. Howell, C. R. 2002. Cotton seedling preemergence damping-off incited by Rhizopus oryzae and Pythium spp. and its biological control with Trichoderma spp. Phytopathology 92:177-180.

27. Howell, C. R. 2003. Mechanisms employed by Trichoderma species in the biological control of plant diseases: The history and evolution of current concepts. Plant Dis. 87:4-10.

28. Howell, C. R., Hanson, L. E., Stipanovic, R. D., and Puckhaber, L. S. 2000. Induction of terpenoid synthesis in cotton roots and control of Rhizoctonia solani by seed treatment with Trichoderma virens. Phytopathology 90:248-252.

29. Hwang, J., and Benson, D. M. 2003. Expression of induced resistance in poinsettia cuttings against Rhizoctonia stem rot by treatment of stock plants with binucleate Rhizoctonia. Biol. Control 27:73-80.

30. Lindsey, D. L., and Baker, R. 1967. Effect of certain fungi on dwarf tomatoes grown under gnotobiotic conditions. Phytopathology 57:12621263.

31. Lorito, M. 1998. Chitinolytic enzymes and their genes. Pages 73-99 in: Trichoderma and Gliocladium. Vol. 2. G. E. Harman and C. P. Kubicek, eds. Taylor \& Francis, London.

32. Lorito, M., Di Pietro, A., Hayes, C. K., Woo, S. L., and Harman, G. E. 1993. Antifungal, synergistic interaction between chitinolytic enzymes from Trichoderma harzianum and Enterobacter cloacae. Phytopathology 83:721-728

33. Lorito, M., Peterbauer, C., Hayes, C. K., and Harman, G. E. 1994. Synergistic interaction between fungal cell wall-degrading enzymes and different antifungal compounds enhances inhibition of spore germination. Microbiology 140:623-629.

34. Lorito, M., Woo, S. L., Donzelli, B., and Scala, F. 1996. Synergistic, antifungal interactions of chitinolytic enzymes from fungi, bacteria and plants. Pages 157-164 in: Chitin Enzymology II. R. A. A. Muzzarelli, ed. Atec, Grottammare (AP), Italy.

35. Lorito, M., Woo, S. L., Garcia Fernandez, I., Colucci, G., Harman, G. E., Pintor-Toro, J. A., Filippone, E., Muccifora, S., Lawrence, C. B., Zoina, A., Tuzun, S., and Scala, F. 1998. Genes from mycoparasitic fungi as a source for improving plant resistance to fungal pathogens. Proc. Natl. Acad. Sci. USA 95:7860-7865.

36. Mandels, M. 1975. Microbial sources of cellulase. Biotechnol. Bioeng. Sym. 5:81-105.

37. Mandels, M., and Reese, E. T. 1957. Induction of cellulase in Trichoderma viride as influenced by carbon sources and metals. J. Bacteriol. 73:269-278 
38. Pieterse, C. M. J., Van Pelt, J. A., Ton, J., Parchmann, S., Mueller, M. J., Buchala, A. J., Metraux, J.-P., and Van Loon, L. C. 2000. Rhizobacteriamediated induced systemic resistance (ISR) in Arabidopsis requires sensitivity to jasmonate and ethylene but is not accompanied by an increase in their production. Physiol. Mol. Plant Pathol. 57:123-134.

39. Pieterse, C. M. J., Van Pelt, J. A., Van Wees, S. C. M., Ton, J., LeonKoosterziel, K. M., Keurentjes, J. J. B., Verhagen, B. W. M., Knoester, M., Van der Sluis, I., Bakker, P. A. H. M., and Van Loon, L. C. 2001. Rhizobacteria-mediated induced systemic resistance: Triggering, signaling and expression. Eur. J. Plant Pathol. 10:751-761.

40. Salvatore, S., Heuschkel, R., Tomlin, S., Davies, S. E., Edwards, S., Walker-Smith, J. A., French, I., and Murch, S. H. 2000. A pilot study of $\mathrm{N}$-acetylglucosamine, a nutritional substrate for glycosaminoglycan synthesis, in pediatric chronic inflammatory bowel disease. Aliment. Pharmacol. Therap. 14:1567-1579.

41. Stasz, T. E., Harman, G. E., and Weeden, N. F. 1988. Protoplast preparation and fusion in two biocontrol strains of Trichoderma harzianum. Mycologia 80:141-150.

42. Viterbo, A., Montero, M., Ramot, O., Friesem, D., Monte, E., Llobell, A., and Chet, I. 2002. Expression regulation of the endochitinase chit36 from Trichoderma asperellum (T. harzianum T-203). Curr. Genet. 42:114-122.

43. Wang, C., Knill, E., Glick, B. R., and Defago, G. 2000. Effect of transferring 1-aminocyclopropane-1-carboxylic acid (ACC) deaminase genes into Pseudomonas fluorescens strain $\mathrm{CHA} 0$ and its gacA derivative CHA96 on their growth-promoting and disease-suppressive capacities. Can. J. Microbiol. 46:898-907.

44. Weindling, R. 1934. Studies on a lethal principle effective in the parasitic action of Trichoderma lignorum on Rhizoctonia solani and other soil fungi. Phytopathology 24:1153-1179.

45. Weindling, R., and Fawcett, H. S. 1936. Experiments in the control of Rhizoctonia damping-off of citrus seedlings. J. Agric. Sci. Calif. Agric. Exp. Stn. 10:1-16.

46. Yedidia, I., Benhamou, N., and Chet, I. 1999. Induction of defense responses in cucumber plants (Cucumis sativus L.) by the biocontrol agent Trichoderma harzianum. Appl. Environ. Microbiol. 653:1061-1070.

47. Yedidia, I., Shoresh, M., Kerem, K., Benhamou, N., Kapulnik, Y., and Chet, I. 2003. Concomitant induction of systemic resistance to Pseudomonas syringae pv. lachrymans in cucumber by Trichoderma asperellum (T-203) and the accumulation of phytoalexins. Appl. Environ. Microbiol. 69:7343-7353.

48. Zeilinger, S., Galhaup, C., Payer, K., Woo, S. L., Mach, R. L., Fekete, C., Lorito, M., and Kubicek, C. P. 1999. Chitinase gene expression during mycoparasitic interaction of Trichoderma harzianum with its host. Fungal Genet. Biol. 26:131-140.

49. Zimand, G., Elad, Y., and Chet, I. 1991. Biological control of Botrytis cinerea by Trichoderma spp. Phytoparasitica 19:252-253. 